\author{
Divna D. Glumac* \\ Univerzitet u Beogradu \\ Filološki fakultet \\ Katedra za orijentalistiku
}

\title{
KAUZATIV GLAGOLA EMOCIJA, PERCEPCIJE I KOGNICIJE U JAPANSKOM JEZIKU
}

\author{
Originalni naučni rad \\ UDC 811.521'367.625 \\ https://doi.org/10.18485/kkonline.2020.11.11.6
}

Predmet rada su rečenice kauzativa glagola emocija, percepcije i kognicije u japanskom jeziku, koje spadaju u kauzativ nevoljnih radnji. Poseban akcenat stavljen je na glagole emocija. Budući da kauzativ glagola emocija nije u prvom planu kada se govori o kauzativu u japanskom, cilj rada je da ukaže na njegove specifičnosti u odnosu na prototipičnu, dvoagentivnu kauzativnu rečenicu. Drugi cilj je da se ukaže na karakteristike kauziranih glagola emocionalnih stanja uopšte, ali i u pojedinim jezicima poput engleskog i srpskog koje se ispoljavaju i u japanskom.

Metodom semantičke analize rasvetlićemo argumentsku strukturu kauzativnih glagola iz perspektive semantičkih uloga koje se dodeljuju sintaksičkim pozicijama subjekta i objekta, sa posebnim akcentom na ulozi subjekta-izazivača. U obzir uzimamo i pojmove voljnosti $i$ intencionalnosti.

Kao i u drugim jezicima, i u japanskom je uočeno da obavezan argument predikata emotivnog stanja jeste propozicione prirode. Tako i izazivač personalnog ili objektnog tipa ima značenje situacije ili događaja, jer promenu stanja doživljavača izaziva nekom svojom osobinom ili radnjom, i oni su primarni uzročnici. Zatim, argument propozicione prirode može biti ekspliciran ili prikriven. U japanskom, eksplicirani se iskazuje klauzom u značenju sredstva ili uzroka, ali može i uslovnom ili vremenskom klauzom. Zatim, kauzativni glagoli emocija i mentalnih stanja dopuštaju angažovanje dopune u značenju sredstva sentencijalnog ili nominalizovanog tipa. Pored navedenih dopuna sentencijalnog tipa, u japanskom se koristi i nominalizovana dopuna u značenju sredstva ili sprovodnika. Ona se može strukturno i semantički objedinjeni sa subjektom-izazivačem u jedan konstituent kada je odnos između sredstva (sprovodnika) i subjekta odnos deo-celina, što je takođe uočeno u drugim jezicima.

Ključne reči: kauzativ, japanski, glagoli emocija, glagoli mentalnih radnji, izazivač, doživljavač.

\section{Uvod}

Kauzativnost se u japanskom jeziku ostvaruje u ekstrapersonalnoj, interpersonalnoj i intrapersonalnoj sferi. Prototipična kauzativna rečenica je dvoagentivna. Učesnici kauzativne situacije koju ona opisuje nastupaju kao agentivna

\footnotetext{
*Filološki fakultet u Beogradu, Studentski trg 3, 11000 Beograd, Srbija; e-mail: azuratdi@gmail.com
} 
i voljna bića, čiju radnju odlikuje intencionalnost. Takve rečenice opisuju kauzativnost voluntativnog tipa. Ovaj rad, međutim, skreće pažnju na kauzativ nevoljnih glagola, kojem posebnu pažnju poklanja Sato (Satō, 1986; 1990). Sato daje sveobuhvatnu klasifikaciju nevoljnih glagola uključujući i glagole psiho-fizičke ili društvene aktivnosti stavljajući naglasak na vrstu entiteta u ulozi direktnog objekta, uključujući tu i neživo. Predmet ovog rada, međutim, predstavljaju kauzativne rečenice glagola emocija, percepcije i kognicije čiji je nosilac animatni personalni argument, sa posebnim osvrtom na vrstu i prirodu entiteta u ulozi izazivača na poziciji subjekta i oblike iskazivanja načina izazivanja promene u doživljavaču.

Oslanjajući se na teorijska dostignuća u oblasti kauzativnosti, pre svega na teoriju Lajonsa (Lyons, 1977) i Van Valina i Lapole (Van Valin \& LaPolla, 1997), ukazaćemo na to kako se svojstva kauzativne rečenice ispoljavaju u rečenici kauzativa glagola emocija, percepcije i kognicije. Tu mislimo na valencu glagola, svojstva učesnika, kao što su animatnost ili personalnost, oblik njihove aktivnosti i dejstva, u okviru kojih sagledavamo voljnost, intencionalnost, situitivnost, eventivnost, agentivnost, kauzalnost i dr. Istraživanje se delom zasniva i na teorijskom pristupu Krofta (Craft, 1993) koji se bavi argumentskom strukturom tzv. mentalnih glagola, posmatrajući situaciju opisanu glagolom kroz odnos izazivača i doživljavača, kao osnovnih uloga argumenata glagola. Sagledavajući osnovne karakteristike kauziranih glagola emocija uopšte, ali i u pojedinim jezicima poput engleskog (Levin, 1993), kao i u srpskom i slovenskim jezicima kroz istraživanja Štrbac (2006), MoskovljevićPopović (2007), Popović (2007), Milenković (2015), pokušaćemo da uočimo koje od njih se uočavaju i u kauzativu glagola emocija, percepcije i kognicije u japanskom.

Posmatramo osobine kauzativnih rečenica kroz primere iz dela savremene japanske književnosti i njihove prevode na srpski. Delimično koristimo i elektronski materijal, prvenstveno korpus savremenog japanskog pisanog jezika (BCCWJ) Nacionalnog instituta za japanski jezik i lingvistiku (NINJAL).

\section{Teorijski okvir - kauzativnost i glagoli mentalnih radnji i stanja}

Kauzativna konstrukcija se definiše kao gramatički produktivni mehanizam kojim se povećava valenca glagola za jedan, što se ostvaruje uvođenjem novog argumenta na mesto subjekta (Lyons, 1977: 486). Za učesnike kauzativne situacije koriste se termini „,kauzator" za inicijatora radnje i „,kauzirani" za vršioca radnje, ${ }^{1}$ pre svega kada

\footnotetext{
${ }^{1}$ Eng. causer i causee. Termine „kauzator" i „kauzirani" koristi Alanović (2010). U novije vreme istraživanjem kauzativnosti u srpskom jeziku bave se Batistić (1978), Alanović (2009), (2010), (2011), (2012), Piper (2005). Vezom kauzativnosti i kauzalnosti bavi se Kovačević (1988). Kontrastivnim proučavanjima
} 
se referiše o učesnicima koje odlikuje svojstvo živo i voljno. U prototipičnoj kauzativnoj rečenici subjekat-kauzator je agens kauzativnosti dok je kauzirani agens radnje glavnog glagola. Za nosioca semantičko-logičke strukture kauzativnih glagola uzima se glagol cause (izazvati) (Lyons, 1977; Van Valin \& LaPolla, 1997). On ima dva argumenta: „[...] cause [semantičko-logička struktura osnovnog glagola]", pri čemu ulogu prvog argumenta ne može zauzeti individua sama po sebi, već to mora biti neko njeno stanje, radnja ili postignuće - dakle uzročno ili podsticajno delovanje - i ono može ili ne mora biti specifikovano (Van Valin \& LaPolla, 1997: 107).

Uočavajući dva tipa kauzativnih rečenica - prvi, kod koga je u ulozi subjekta svesni agens koji voljno izaziva određenu situaciju i drugi, kod koga jedna situacija, događaj, stanje ili proces izaziva nastajanje druge situacije, Lajons (1977: 490) pod pojmom kauzativnosti obuhvata i agentivnost i kauzalnost ${ }^{2}$. Prototipična dvoagentivna kauzativna rečenica izražava delovanje na volju drugog, personalnog argumenta da izvrši radnju. To je kauzativnost voluntativnog tipa i ona obuhvata voljne glagole. Tu je kauzator argument sa obeležjima animatnosti, personalnosti, intencionalnosti i voljnosti, a akcenat se stavlja na pojavu kauziranog događaja. Eventivni i situativni kauzatori, kao oblik kauzatorove aktivnosti, tip događaja i okolnosti koje su uzrokovale kauziranu situaciju zauzimaju perifernu poziciju i ne iskazuju se eksplicitno.

Osim što se ostvaruje u sferi voljnih glagola, kauzativnost se ostvaruje i delovanjem na emocionalni stav drugog (Cruse, 1972). Na taj način širi se semantičko polje kauzativnosti. Tada u ulozi kauzatora mogu biti i pojave i predmeti, koje odlikuje odsustvo kategorijalnih obeležja animatno i voljno, te se onda ne može govoriti o ciljnousmerenom delovanju. U rečenicama kauzativa glagola emocija upravo su eventivni i situaitivni kauzatori nosioci kauzirajuće situacije, a kada je kauzator animatni i personalni argument on nije uzročnik sam po sebi niti nastupa kao voljno i intencionalno biće već primarni uzrok postaju njegova osobina, aktivnost, ponašanje, koji u kauziranom spontano izazivaju promenu, te se i personalni kauzator izjednačava sa događajem.

Kada su u osnovi kauzirane situacije glagoli emocija, radnja živog i personalnog argumenta u ulozi kauziranog odlikuje se odsustvom odlike voljnosti, te se o njemu ne može referisati kao o agensu. U ovom radu koristićemo termine "izazivač" i

kauzativnosti u srpskim i drugim jezicima bave se Glumac (2015), (2016), (2017), Bilandžija (2014), Ristivojević-Rajković (2017).

${ }^{2} \mathrm{U}$ radu, terminom „kauzativnost" označavamo univerzaliju formalizovanu na različitim jezičkim nivoima morfološkom, derivacionom, leksičkom i sintaksičkom, a terminom „kauzalnost" označavamo odnos između entiteta, pojava i događaja vanjezičkog sveta, koji karakteriše vremenski i uzročni sled. 
"doživljavač"3 kada se ukazuje na osnovne semantičke uloge argumenata ovih glagola (up. Štrbac, 2006).

Glagole emocija, percepcije i kognicije Kroft (Croft, 1993) naziva mentalnim glagolima, a tu obuhvata glagole percepcije, kognicije i emocija, i deli ih na statične i kauzativne, prema tome da li je uloga doživljavača pripisana subjektu ili objektu. Kod statičnih glagola (tipa voleti) doživljavač je na mestu subjekta a akcenat je na doživljaju odnosno stanju, dok je kod kauzativnih glagola (tipa zadovoljiti) doživljavač na mestu objekta a akcenat je na uzročno-posledičnom odnosu između subjektaizazivača i objekta-doživljavača promene stanja. Taj odnos predstavlja u formi dvosmernog uzročnog lanca, u čijoj osnovi je koncept delovanja jednog učesnika na drugog. Doživljavač usmerava svoju pažnju na izazivača-uzročnika, koji, kao posledicu, u njemu uzrokuje promenu psihološkog stanja. Kroft (1993: 62) na taj način definiše kauzalnu strukturu kauzativnih mentalnih glagola, dok statične glagole određuje kao stanje koje ne uključuje prenos dejstva. Iz navedenog proizilazi i jedna od razlika između ovih glagola, a to je angažovanje dopune u značenju sredstva, bilo da je ona sentencijalnog ili nominalizovanog tipa. Dok kauzativni glagoli imaju mogućnost iskazivanja ove dopune (John pleased his boss by coming in early every

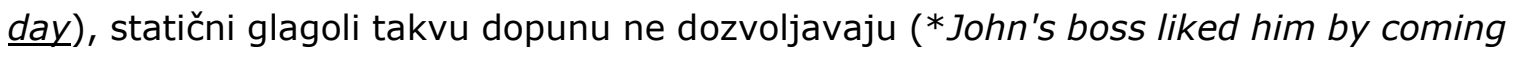
in early every day), već umesto toga zahtevaju uzročnu dopunu (John's boss liked him because he [=John] came in early every day) (Croft, 1993: 57).

Glagole koji iskazuju iniciranje emocije Štrbac (2006) naziva tzv. "glagolima kauziranih emotivnih stanja". Oni su semantički i sintaksički izvedeni iz tzv. "glagola emotivnih stanja", i u njihovoj semantičkoj interpretaciji koristi se faktitivna forma (u)činiti da, kojom se naznačava da je do pojave nekog osećanja došlo tako što ga neko svesno i intencionalno kauzira, odnosno forma izaz(i)vati da, ukoliko je izazivač emocije neživi pojam ili se intencionalnost ne podrazumeva (Štrbac, 2006: 81). Semantička struktura glagola kauziranih emotivnih stanja nastaje uvođenjem pojma kojim se iskazuje kauzator ili uzročnik emotivnog stanja, čime neprelazni glagol emotivnog stanja postaje dvovalentan a rečenična struktura se proširuje. U funkciji dopune glagola kauziranih emotivnih stanja je obavezno leksema sa obeležjem živo /+/ i ona ima ulogu doživljavača emotivnog stanja, dok leksema u ulozi izazivača može i ne mora posedovati dato obeležje.

\footnotetext{
${ }^{3}$ Eng. stimulus i experiencer (Levin 1993, Kroft 1993). U literaturi se o stimulusu govori i kao o kauzatoru ili uzročniku emotivnog stanja (up. Moskovljević-Popović 2007).
} 
Proučavajući argumentsku strukturu glagola emotivnog stanja u slovenskim jezicima, Popović (2007) polazi od stava da je emocionalno stanje reaktivno stanje koje nastaje usled doživljaja različitih događaja, i tvrdi da je obavezan argument predikata emotivnog stanja propozicione prirode, jer reakcija subjekta podrazumeva događaj koji joj prethodi. Propozicioni argument može da bude ekspliciran (Ivan se plaši da će ga Nikola povrediti), ali i prikriven (Ivan se plaši Nikole) (Popović, 2007: 486).

Glagole za izražavanje psiholoških stanja, osećanja i raspoloženja u srpskom Moskovljević-Popović (2007) deli na jednovalentne (tugovati), dvovalentne (voleti) i trovalentne (plašiti), ističući kauzativni odnos kao odliku dvovalentnih i trovalentnih. Dok su u rečenicama sa dvovalentnim glagolima moguće različite raspodele tematskih uloga između izazivača i doživljavača, jer svaki može zauzeti mesto subjekta, direktnog ili indirektnog objekta, Moskovljević-Popović ističe da je uz trovalentne gramatički subjekat uvek izazivač a objekat je doživljavač. Kod ovih glagola treći argument je fakultativna dopuna u slobodnom instrumentalu u ulozi sredstva ili sprovodnika i „označava biće, predmet, ili pojavu kojim, odnosno, čime stimulus u doživljavaču izaziva osećanje ili raspoloženje izrečeno glagolom" (MoskovljevićPopović, 2007: 88). Rečenični tip sa ovim glagolima kod kojih je izazivač u ulozi subjekta, doživljavač imenica u ulozi objekta, a sredstvo ili sprovodnik u slobodnom instrumentalu (Marko iznenađuje Anu svojim stavovima), može da se realizuje i u „značenjski korespondentnim rečeničnim konstrukcijama u kojima gramatički subjekat i dopuna u instrumentalu bivaju strukturno i semantički objedinjeni u jedan konstituent (Markovi stavovi iznenađuju Anu / Ana je iznenađena Markovim stavovima)" (Moskovljević-Popović, 2007: 88). Čini se da je ova tvrdnja primenljiva u slučajevima kada je odnos između kauzatora i sprovodnika odnos deo-celina ili u širem smislu odnos posesije. ${ }^{4}$

\section{Kauzativ u japanskom - dosadašnja istraživanja}

Kategorija kauzativnosti u japanskom gramatikalizovana je u vidu pomoćnog glagola saseru, čiji je nosilac morfema sase, ${ }^{5}$ a sintaktizovana je u formi proste rečenice "N-wa N-ni/wo $\mathrm{V}_{\text {it }}$-saseru"6 odnosno "N-wa N-ni N-wo $\mathrm{V}_{\text {tr }}$-saseru" (za dodatne

\footnotetext{
${ }^{4}$ O odnosu posesije više u Stojanović (1996), a o odnosu deo-celina više u Ivić (1983).

${ }^{5}$ Pomoćni glagol saseru onosno morfema sase imaju i oblik -aseru odnosno -ase, u zavisnosti od oblika osnove glagola na koji se dodaju. Kod jednosamoglasničkih glagola imaju oblik saseru /sase (taberu $\rightarrow$ tabesase-ru), dok oblik -aseru /-ase imaju kod petosamoglasničkih glagola (okuru $\rightarrow$ okur-ase-ru).

${ }^{6} \mathrm{U}$ japanskom jeziku odnos imenskih reči prema predikatu izražava se padeškim pomoćnim rečcama. Od navedenih, jedino rečca wa nema padešku ulogu već označava subjekat ili temu. Značenje ostalih padeških
} 
detalje up. Glumac 2015). Morfema sase dodaje se u vidu afiksa na osnovu prelaznog ili neprelaznog glagola, što za posledicu ima povećavanje valentnosti, a njeno prisustvo sistematski ukazuje na razliku između nekauzativne i kauzativne upotrebe glagola, npr. tabe-ru (jesti) i tabe-sase-ru (učiniti da /neko/ jede). Na taj način nastaje jedan složen glagolski oblik, kojim se iskazuju i kauzirajuća i kauzirana radnja, tako da oblik delovanja kauzatora nije eksplicitno dat niti je iskazan u vidu zasebne propozicije, već je izražen uopšteno, pomoćnim kauzativnim glagolom saseru. Morfema sase odlikuje se izrazito visokim stepenom produktivnosti. Nosioci dveju radnji zauzimaju poziciju subjekta (kauzator) i dopune (kauzirani tj. vršilac radnje aktiva).

Pomenuta sintaksičko-semantička svojstva dala su osnov za različite klasifikacije kauzativne rečenice u japanskom jeziku. Tako su nastale različite podele zasnovane na morfo-sintaksičkim, sintaksičkim i / ili semantičkim svojstvima kauzativne rečenice: direktni i indirektni kauzativ, kauzativ prelaznih i kauzativ neprelaznih glagola; "wo kauzativ" i "ni kauzativ" i dr. ${ }^{7}$ Najčešća je uopštena podela na kauzativ prisile i kauzativ dozvole (Kuroda, 1965; Suzuki, 1972; Shibatani, 1973; Teramura, 1982; Hayatsu, 2004 i dr.).

Upotreba kauzativa u japanskom jeziku objašnjava se tačkom gledišta ili perspektivizacijom. Morita (1971) definiše kauzativ i pasiv kao iskaze u kojima se događaj opisuje sa tačke gledišta onoga ko nije agens. Slično, Suzuki (1972: 285) određuje kauzativ i pasiv u okviru kategorije glagolskog roda pojmom tačke gledišta (tachiba) odnosno time da li će se na mesto subjekta odnosno objekta iskaza staviti vršilac ili predmet radnje, ili treće lice koje je u bilo kakvom odnosu s radnjom. Teramura (1982: 289) posmatra kauzativnu rečenicu kao rečenicu sa umetnutom ili uklopljenom strukturom, koju čine kauzirajuća i kauzirana situacija, a njen nastanak objašnjava uvođenjem novog lica na mesto subjekta i promenom perspektive.

Uočavajući gradaciju u stepenu dejstva i u prisustvu namere kauzatora u izazivanju radnje drugog lica ili predmeta, od direktnog, jednosmernog i aktivnog ka indirektnom i pasivnom, Morita (1971: 36-37) navodi sledeća značenja kauzativne rečenice u japanskom: prelaznost; prisila; izazivanje promene; dozvola, ostavljanje ili puštanje; odgovornost ili osobina; uzročno-posledični odnos. Ovo polazište je poslužilo kao osnova kasnije podele kauzativa na direktni i indirektni. Suzuki (1972) uopštava ova značenja, podvodeći ih u sledeća: aktivno prisiljavanje drugoga na radnju; pasivno

pomoćnih rečci je sledeće: wo - akuzativ / direktni objekat; ni - dativ / indirektni objekat; agentivna dopuna.

7 Podela na "wo kauzativ" i „ni kauzativ" izvršena je prema padeškoj pomoćnoj rečci kojom se u kauzativnoj rečenici označava agens radnje iskazane leksičkim glagolom (Kuroda, 1965). 
davanje dozvole za radnju; značenje uzroka kada je subjekat kauzativne rečenice neživo.

Morita je ukazao na problem nevoljnih glagola izdvajajući značenje izazivanja promene, koje objašnjava kao pasivno i indirektno dejstvo kauzatora koji nekom svojom radnjom stvara povod za izazivanje radnje ili promene stanja entiteta u ulozi objekta, što je dalo osnov za nove podele, među kojima je i ona koju nudi Sato (1986) na kauzativ voljnih i kauzativ nevoljnih glagola, a koje uključuju i promenu psihičkih i fizioloških stanja. O tzv. "kauzativu nevoljne radnje”, periferno, bavili su se i Takahaši (Takahashi, 2005) i Hajacu (Hayatsu,2004).

Detaljniju semantičku analizu kauzativne rečenice ponudila je Sato (1986) u okviru svoje podele na kauzativ voljnih i kauzativ nevoljnih glagola. U glavna značenja kauzativa voljnih glagola ubraja ranije utvrđena značenja naredbe, dozvole, puštanja, zabrane ili ostavljanja, dok kod kauzativa nevoljnih glagola, pod kojim obuhvata glagole koji izražavaju psiho-fizičke ili društvene aktivnosti i stanja, kao što su: hizamazuku (klečati), magotsuku (oklevati), chokumen suru (suočiti se sa), katan suru (podržati) (Satō, 1986: 143-145), kao glavno izdvaja značenje izazivanje promene. Navedena značenja određuju sledeći faktori: kategorijalno obeležje živo / \pm / učesnika kauzativne situacije; voljnost glavnog glagola; potvrdan ili odričan oblik kauzativnog glagola (saseru / sasenai); davanje / primanje koristi ili štete; prisustvo namere u dejstvu kauzatora (Satō, 1986: 90).

Kauzativ nevoljnih glagola Sato (1990) razmatra u okviru kauzativnih rečenica koje izražavaju uzročno-posledični odnos, koje deli na one sa prelaznim i one sa neprelaznim glagolima. U ove potonje svrstava i glagole psihičkih radnji u širem smislu, kao što su glagoli mišljenja, osećanja, opažanja, jezičkih aktivnosti (Satō, 1986: 152).

Sato (1990) daje klasifikaciju uzročnih kauzativa nevoljnih glagola na osnovu vrste entiteta u ulozi direktnog objekta, uključujući tu i neživo. S druge strane, naglašava da u ulozi izazivača promene jesu pojave i događaji, dok personalni argument u ulozi subjekta ne može biti uzrok samo po sebi, već je to neka njegova osobina ili ponašanje, te i on dobija značenje događaja. U zavisnosti od semantičkih svojstava glagola, pre svega obeležja voljno, određuju se i semantičke uloge animatnog, personalnog subjekta-kauzatora, te on nastupa kao aktivni podstrekač, što je slučaj kod kauzativa voljnih glagola, ili ima eventivni karakter, u slučaju kauzativa nevoljnih glagola (Satō, 1990: 106). 
Ističući neophodnost iskazivanja stanja, osobine, čina ili sadržaja predmeta, bića, odnosno događaja na mestu subjekta, navodi da uzročni događaj može biti iskazan imenicom ili nominalizovanom glagolskom ili pridevskom frazom uz nominalizator no ili koto, zatim kontekstualno, zasebnom rečenicom ili nezavisnom klauzom u okviru složene rečenice, kada se na njega ukazuje pokaznom zamenicom sore (to) u ulozi subjekta kauzativne rečenice (Satō, 1990: 110-111).

Iz navedenog sledi da se kao važni kriterijumi klasifikacije kauzativa u japanskom uzimaju kategorijalna obeležja učesnika kuzativne situacije, od kojih je naročito bitno obeležje živo, što se u širem smislu može shvatiti kao agentivnost. Kauzator može biti živo biće, koje svojim svesnim i voljnim delovanjem pokreće neki drugi entitet na radnju, a može biti i situacija, koja predstavlja uzrok radnje drugog. Na osnovu prisustva obeležja živo, kauzativi se dele na dvoagentivne i jednoagentivne (up. Alanović, 2010: 365). Dvoagentivni su oni gde i nosilac kauzirajuće i nosilac kauzirane situacije deluju kao agensi. Ulogu kauzatora ne može zauzeti biće samo po sebi, već to mora biti neka njegova radnja, stanje ili postignuće. U dvoagentivne kauzative u širem smislu ubrajaju se oni kod kojih je u ulozi kauzatora umesto živog bića njegova akcija, osećanje, odnosno manifestacija osećanja, emocija, poput tuge, ćutanja, obećanja i sl. Na mestu objekta kauzativnih glagola dvoagentivnih rečenica, po pravilu stoje imenice koje označavaju ljude, ređe životinje. Kauzator svesno i namerno deluje na kauziranog, čime ovaj ostvaruje zadati rezultat (up. Glumac 2015).

Japanska kauzativna rečenica u svom prototipičnom značenju izražava dvoagentivnu situaciju, u kojoj oba učesnika odlikuju značenja animatno, personalno i voljno. Ona je heterosubjekatska struktura koja istovremeno izražava i radnju agensa-kauziranog i ističe odgovornost drugog lica, kauzatora, dodeljujući mu ulogu subjekta.

Kauzativ u japanskom obuhvata i intrapersonalne i ekstrapersonalne odnose, kod kojih se pre može govoriti o kauzalnosti nego o agentivnosti i voljnosti. Takve su rečenice kauzativa posesije, kauzativa uzroka ili kauzativa delovanja na osećanja drugog. Delovanje na emocionalni stav drugog iskazuje se upotrebom kauzativa neprelaznih glagola koji izražavaju osećanja, a koji se u nekim klasifikacijama svrstavaju u kauzativ nevoljne radnje (Satō, 1986; Takahashi, 2005), ili u kauzativ odnosa posesije u najširem smislu, pri čemu se u neotuđivu svojinu osim dela tela ubrajaju i svojstva, emocije, mentalne aktivnosti i proizvodi tih aktivnosti (Hayatsu, 1991). U oba slučaja dovode se u vezu sa uzročno-posledičnim dejstvom (Satō, 1986; Hayatsu, 1991, 2004; Iori, 2002). Iako uzročno-posledični odnos može da se uspostavi 
i između stvari i pojava, oni neće biti predmet ovog istraživanja. Obuhvatićemo samo situacije kod kojih je kauzirani-doživljavač personalni argument, dok na mestu kauzatora-izazivača može da stoji i argument koji ne poseduje odlike animatnosti, voljnosti i intencionalnosti.

\section{Kauzativ glagola emocija, percepcije i kognicije u japanskom jeziku}

Pod glagolima emocija podrazumevamo glagole psiholoških stanja, osećanja i raspoloženja, koji su u japanskom neprelazni: kinchō suru (strepeti), komaru (brinuti), manzoku suru (biti zadovoljan), yorokobu (radovati se), okoru (ljutiti se) i dr. U njih svrstavamo i nevoljne glagole naku (plakati) i warau (smejati se), koji kao glagoli fiziološke emocionalne ekspresije predstavljaju reakcije na emocije tuge odnosno radosti. Glagoli percepcije i kognicije u širem smislu ovde obuhvataju kognitivne, perceptivne i glagole mišljenja ili intelektualnih radnji: omou (misliti); kanjiru (osetiti); omoidasu (setiti se); sōzō suru (zamisliti; pretpostaviti) i dr. Tu su još i glagolski izrazi koji za dopunu imaju opštu imenicu kanjō (osećaj, osećanje), a ona mora biti bliže određena atributom.

Glagoli emocija su neprelazni dok su glagoli percepcije i kognicije po pravilu prelazni. Neprelazni glagol emocionalnog stanja u kauzativnom obliku postaje prelazan, a ulogu direktnog objekta dobija animatni i personalni doživljavač odnosno nosilac stanja. Kod glagola , percepcije i kognicije doživljavač dobija ulogu indirektnog objekta, jer poziciju direktnog zauzima predmet opažanja, osećanja, mišljenja i dr. Na mestu subjekta mogu biti različiti entiteti - ljudi, predmeti, bića, apstraktne pojave, situacije, događaji, kao i zamenica sore (to) kojom se ukazuje na predmetni ili situativni kauzator. Između kauzativa nevoljnih radnji i osećanja i glagola u osnovi postoji formalna veza, npr. okoru (ljutiti se) - okoraseru (ljutiti).

Personalni i voljni kauzator može da izaziva nevoljnu radnju ili osećanje drugog lica i namerno. On tada vrši voljnu radnju koja ima za cilj da izazove određena psihološka stanja u drugom licu, a njegova namera proteže se i na kauziranu radnju odnosno stanje. Kauzator onda ima ulogu aktivnog izazivača, a ove dve radnje odnose se kao „sredstvo i cilj" (Satō, 1986: 149). Mnogo su češći slučajevi, međutim, kada kauzator izaziva pomenuta stanja samo svojom osobinom, svesnim ili nesvesnim ponašanjem ili radnjom i bez učešća svoje volje i namere. Upotrebom kauzativa neprelaznih glagola koji izražavaju osećanja u prvi plan se stavlja pojava datog osećanja u doživljavaču i nevoljnost te radnje a ne intencionalnost kauzatora u izazivanju datog stanja. Ovaj tip kauzativne rečenice više izražava uzročnu vezu 
između pojava. Čak i kada se subjekat kauzacije na površinskoj ravni rečenice pojavljuje kao personalni argument, on ne deluje kao voljno i agentivno biće, već mu je dato značenje događaja ili propozicionog argumenta (up. Popović, 2007).

U situacijama koje se u japanskom jeziku opisuju kauzativom glagola emocija uzročnik je po pravilu spoljašnji. Najčešće je reč o pasivnom uzroku.

\section{Oblik kauzirajućeg delovanja}

Za razliku od dvoagentivne kauzativne rečenice, gde se po pravilu oblik kauzatorovog delovanja ne specifikuje, oblik dejstva izazivača biva iskazan u rečenici kauzativa glagola emocija, i to umetnutom zavisnom klauzom, ili nekim drugim gramatičkim sredstvima. To može biti:

a) zavisna rečenica sa glagolom u vezivnom obliku + te/de:

1 彼女は、「...」と言いふらしてて、わざわざやってきた暇な友人達を＼cjkstart怒らせた。 (BCCWJ)

Kanojo-wa, [...] to iifurashi-te, wazawaza yatte kita himana yūjintachi-wo okor-aseta.

ona [subj.] širiti glasine [vezivni oblik] prijatelji [dir.obj.] naljutiti se [kauzativ] ${ }^{8}$

Ona je, širećci glassine [da ...] naljutila prijatelje koji su imali slobodnog vremena i potrudili se da dođu.

Vezivni oblik + te/de ima primarno značenje sredstva i način vršenja radnje glavnog, ovde kauzativnog glagola, ali ima i uzročno značenje, a uloga izazivača približava se ulozi uzročnika. Budući da izazivač nije uzrok sam po sebi, u rečenicama kauzativa glagola emocija iskazivanje oblika delovanja kauzatora postaje neophodno.

b) uslovna klauza (V-to):

2 二人がー緒になると、その組み合わせは僕をひどく疲れさせた。(Murakami， 1988b: 207)

\footnotetext{
8 Prilikom morfo-sintaksičke analize ukazujemo samo na rečenične elemente koji su u direktnoj vezi sa kauzativnim glagolom, kao glavne dopune predikata: subjekat (subj.), direktni objekat (dir.obj.), indirektni objekat (ind.obj.), glagol u osnovi predikata uz kauzativni pomoćni glagol odnosno morfemu (kauzativ). Pored njih, navodimo i pojedine rečenične elemente koji su u službi isticanja oblika kauzirajućeg dejstva, poput imenice označene padeškom rečcom de u značenju instrumentala sredstva (inst.), no u značenju genitiva pripadnosti (gen.) i sl.
} 
Futarari-ga issshoni naru ton tono kumiawase-wa boku-wo hidoku tsuk-aresaseta.

[njih dve [subj.] zajedno biti [uslovna kl.]] ta kombinacija [subj.] ja [dir.obj.] biti iscrpljen [kauzativ]

Kad su njịh dve zajedno 2013: 330)

Okolnost pod kojom se javlja stanje iskazana je uslovnom klauzom, a zatim se na nju anaforički ukazuje i apstraktnom zamenicom sono uz imenicu kumiawase (ta kombinacija) u ulozi subjekta glavne, kauzativne rečenice.

c) priloška odredba kojom se ukazuje na okolnosti:

3 坊さんがその点でKを満足させたかどうかは疑問ですが[...] (Soseki，1965: 488)

Bōsan-ga sono ten-de $\mathrm{K}$-wo manzoku saseta ka dōka gimon desuga.

sveštenik [subj.] taj pogled [lok.] $\quad \mathrm{K}$ [dir.obj.] biti $\quad$ zadovoljan [kauzativ]

Ne znam da li je sveštenik un tom pogledu uspeo da zadovolji njegovu znatiželju [K-a] (Soseki, 2003: 202)

Okolnost je iskazana izrazom sono ten-de (u tom pogledu), gde padeška pomoćna rečca de označava mesto, oblast ili sferu u okviru koje se ostvaruje radnja.

d) nominalizovana glagolska ili pridevska fraza uz nominalizator no ili koto (up. Satō, 1990: 110):

4 特に旧ハプスブルク帝国領ブコヴィナを併合したことは、ヒトラーを怒らせた。 (NIDS)

Tokuni kyū Habusuburku tēkoku ryō Bukovinana-wo hēgō shita koto-wo-wa, Hitorāwo okor-aseta.

[nominalizovana glagolska ili pridevska fraza, subj.]

Hitler [dir.obj.] ljutiti se [kauzativ]

Anekssija Buknovine koja je nekada bila deo Habzburške monarhije, je naročito razljutila Hitlera. 
e) kontekst, zasebna rečenica ili nezavisna klauza u okviru složene rečenice, odnosno anafora, kada se na kauzirajući događaj upućuje pokaznom zamenicom sore (to) (up. Satō, 1990: 111):

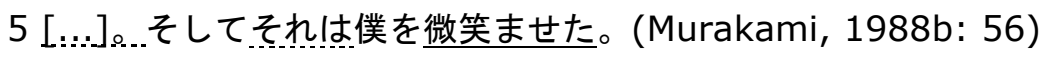

[...]. Soshite sore-wa boku-wo hohoem-aseta.

to [subj.] ja [dir.obj.] nasmejati se [kauzativ]

[.... I. I to me je nasmejalo. (Murakami, 2013: 243)

f) atributiv kojim se ukazuje na neku specifičnu karakteristiku, stanje ili osobina entiteta u ulozi izazivača (up. Satō, 1990: 111):

6 だが、この＼cjkstart私は、彼らを怒らせたのだ。(BCCWJ)

Daga, kono watashi-wa, karera-wo okor-aseta noda.

ovakav ja [subj.] oni [dir.obj.] naljutiti se [kauzativ]

Ali, ja ovakava kakava sam, razljutio sam ih.

g) posebne konstrukcije i oblici za isticanje kojima se ukazuje na neku specifičnu karakteristiku, stanje ili osobina entiteta u ulozi izazivača, poput rečenične strukture "imenica-to (iu no) wa ... glagol-noda": ${ }^{9}$

7 あなたってわりに人のことを落ち込ませるのね。(Murakami，1988b: 86)

Anata-tte warini hitono koto-wo ochikom-aseru none.

ti [naglašena tema] čovek [dir.obj.] oneraspoložiti se [kauzativ]

Tii baš unmešs da oneraspoložiš čoveka. (Murakami, 2013: 260)

\section{Analiza rečenica kauzativa glagola emocija, percepcije i kognicije u}

\section{japanskom}

Zbog sintaksičko-semantičkih razlika između glagola emocija i glagola percepcije i kognicije, posmatraćemo ih zasebno.

\subsection{Kauzativ glagola emocija}

Glagoli emocija su po pravilu neprelazni i u kauzativu postaju prelazni, sa doživljavačem u ulozi direktnog objekta, označenog rečcom wo. Na mestu subjekta je izazivač, označen rečcom wa ili ga. Ove rečenice ćemo grupisati prema vrsti entiteta u ulozi izazivača jer pokazuju specifičnosti u tom pogledu. Čovek, čovekove aktivnosti

\footnotetext{
${ }^{9}$ Navedena struktura se koristi za definisanje, objašnjenje, tumačenje pojave označene imenicom. Njome se iskazuje osobina, značenje ili sadržaj pojave. Govorni oblik je „imenica-tte", i on je upotrebljen u primeru. Up. Jamasaki, 2014: 201.
} 
ili proizvodi tih aktivnosti, predmetni, mesni ili apstraktni entitet u ulozi izazivača ne mogu biti uzročnik sami po sebi, već je to neka njihova specifična osobina ili svojstvo, koji se u rečenici proste strukture, tj. kada oblik dejstva izazivača nije iskazan, moraju bliže odrediti nekim modifikatorom, ili eksplikacijom uzroka kauzacije.

U sledećoj rečenici izazivač je čovek:

1 殊に内供を怒らせたのは、例の悪戯な中童子である。(Hana)

Kotoni Naigu-wo okor-aseta nowa, rēno ittazuranna_chūdōshi dearu.

Naigu [dir.obj.] ljutiti se [kauzativ] nestašni mladi sluga [imenski deo predikata]

A onaj koji je Naigua posebno ljutio, bio je nestaššñ mladi sluga. (Akutagava, 2002: 12)

U rečenici 1 osobina izazivača je eksplicitno iskazana pridevskim atributom, itazurana uz imenicu izazivača (nestašni mladi sluga). Kada je izazivač iskazan imenicom u okviru rečenične strukture „imenica-tte... glagol-noda" (5. poglavlje, primer 7), isticanje osobine ili svojstva pojma iskazanog imenicom u prevodu se može iskazati glagolom umeti sa dopunskom rečenicom. Intencionalnost u izazivanju promene doživljavača nije odlika izazivača, jer je primarni uzrok njegovo stanje ili osobina, na koje on svojom voljom ne utiče.

Sledeće rečenice u ulozi izazivača imaju ljudske aktivnosti ili jezičke, govorne i zvučne proizvode tih aktivnosti:

2 Kは中学にいた頃から、宗教とか哲学とかいうむずかしい問題で、私を困らせました。 (Soseki, 1965: 471)

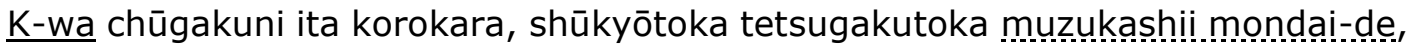
watashi-wo komar-aseta.

K [subj.] teška pitanja [inst.] ja [dir.obj.] biti zbunjen[kauzativ]

Još od gimnazijskih dana $\underline{\mathrm{K}}$. me je zbunjivao tešškim pitanjanjima iz religije i filozofije. (Soseki, 2003: 180)

3 でも彼女の声の小ささが僕を緊張させた。(Murakami, 1988a: 18)

Demo kanojo-no koe-no chiișasa-ga boku-wo kinchō saseta. ona [gen.] glas [gen.] tišina [subj.] ja [dir.obj.] strepeti [kauzativ] 
Ali ñjen tihi glas me je uznemirio. (Murakami, 2013: 14)

4 その視線は僕をどきどきさせた。(Murakami, 1988a: 200)

Sono shisen-wa boku-wo dokidoki saseta.

taj pogled [subj.] ja [dir.obj.] zadrhtati (od straha) [kauzativ]

Ali mi je zbog tog_pogleda srce jako zakucalo. (Murakami, 2013: 123)

U rečenici 2, u ulozi izazivača je čovek dok je neposredni uzročnik, imenica proizvoda ljudske aktivnosti muzukashii mondai (teška pitanja), označena pomoćnom padeškom rečcom de u značenju sredstva. U rečenici 3, u ulozi subjekta je apstraktna imenica chiisasa ("malenost") u imeničkoj frazi koe no chiisasa ("tihost glasa"), kao upravni član konstrukcije "imenica-no", koja odgovara genitivu u srpskom. U obliku „imenica-no" su i personalni izazivač stanja (ona), kao i proizvod čovekove aktivnosti (glas) u ulozi sredstva ili sprovodnika izazivanja promene stanja. Oni su objedinjeni u jedan konstituent. O takvim primerima u engleskom govori Levin (1993: 199) i u srpskom Moskovljević-Popović (2007: 89). U primeru 4, glagol dokidoki suru (zadrhtati, kucati, lupati od uzbuđenja, straha; o srcu) spada u onomatopejične glagole koji podražavanjem zvukova iskazuju pojave u spoljašnjem svetu kao i psihofizička i fiziološka stanja čoveka. U ulozi subjekta je imenica shisen (pogled), uz pokazni pridev sono (taj), upotrebljen kao anafora a u ulozi modifikatora. Iako nije nužna, intencionalnost izazivača mogla bi da se očita u navedenim primerima, i to samo do one tačke dokle je neposredni uzročnik promene stanja doživljavača proizvod svesne i voljne radnje lica u ulozi izazivača.

U sledećim primerima u ulozi izazivača su apstraktni, predmetni i mesni entiteti:

5 部屋の中の静けさは僕をたまらない気持ちにさせた。(Murakami，1988b: 263)

Heya-no naka-no shizukesa-wa boku-wo tamaranai kimochi-ni saseta.

soba [gen.] unutrašnjost [gen.] tišina [subj.] ja [dir.obj.] uznemiriti se [kauzativ]

Tišina u sobi me je ispunila nemirom. (Murakami, 2013: 363)

6 私を驚かせた ハンケチ付きの古い麦葍帽子が閑却されるようになった。(Soseki， 1965: 422) 
Watashi-wo odorokaseta hankachidzuki-no furui mugiwarabōshi-ga kankyaku sareruyōni natta.

ja [dir.obj.] iznenaditi se [kauzativ] maramica [gen.] stari slamnati šešir [subj.]

Stari slamnati šešir sa peškirićem, koji me je tako iznenadio kad sam ga ugledao na ocu, sada je bio odložen. (Soseki, 2003: 110)

7 それともあなたはあまりにもクールで、あなたを驚かせるにはローマぐらいで足りない かもしれない。(Murakami，2001: 103)

Soretomo anata-wa amarinimo kūrude, odorokaseru niwa Rooma gurai de tarinai kamoshirenai.

ti [dir.obj.] iznenaditi se [kauzativ] Rim [imenski deo predikata]

Ili si možda toliko cool da čâk no Rim neće biti dovoljan da te iznenadi. (Murakami, 2004: 74)

Imenica u ulozi izazivača u primeru 5, shizukesa (tišina), bliže je određena genitivnom konstrukcijom u službi prostorne odredbe, heya-no naka-no (u sobi), a imenica u primeru 6 mugiwarabōshi (slamnati šešir) pridevom furui (stari) u službi modifikatora i imenicom hankachidzuki (prikačeni peškirić) uz rečcu no u značenju genitiva ticanja. U primeru 7, uz toponim Rim nije dat nikakav modifikator već je upotrebljen u konotativnom značenju (čuveni, veliki, atraktivni i sl.), koje je pojačano rečcom gurai (ovde: „čak").

\subsection{Kauzativ glagola percepcije i kognicije}

Glagoli percepcije i kognicije najčešće su prelazni, a u kauzativnoj rečenici postaju ditranzitivni, sa kauziranim na mestu indirektnog objekta, označen padeškom rečcom ni. Rečenice najpre delimo prema vrsti glagola predikata, i to na rečenice $s$ glagolom kanjiru (osetiti), na rečenice kod kojih je dopuna direktnog objekta kauzativnog glagola imenica kanjō (osećanje, osećaj) i na rečenice s glagolima kognitivnih i intelektualnih radnji. Potom rečenice delimo prema vrsti entiteta u ulozi direktnog objekta.

U rečenicama koje na mestu predikata imaju kauzativ glagola kanjiru (osetiti), izazivač-uzročnik je najčešće neživo - predmet, pojava ili situacija. 
U sledećim rečenicama imenica na mestu direktnog objekta konkretizuje vrstu osećaja:

1 彼女はきょう話そうと思って来た事を..話せば今が好い折だとは思いながら、父親に、 新しい苦痛を感ぜさせるのがつらいからである。(Gan)

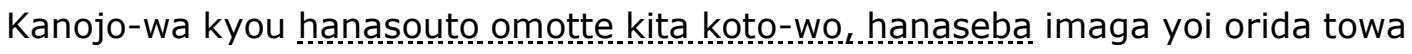
omoinagara, chichioya-ni, atarashii kutsū-wo kanji-saseru noga tsuraikaradearu.

ona [subj.] otac [indir.obj.] bol [dir.obj.] osećati [kauzativ]

Bila je svesna da je sada prava prilika da mu kaže kno ono što je nameneravala al ali bilo joj je mrsko da ona svom ocu ponovo nanosi bol. (Ogai 2014: 55)

$2[\ldots]$ 、女が買おうと思う品物はその女に強烈な苦痛を感ぜさせる。(Gan)

[...], onna-ga kaō to omou shinamono-wa sono onna-ni kyōretsuna kutsū-wo kanji-saseru.

$$
\text { predmet [subj.] žena [indir.obj.] bol }
$$

[dir.obj.] osećati [kauzativ]

[...], predmet koji bi htela da kupi, ženi zadaje silan bol. (Ogai, 2014: 99)

3 見る人に蕰かみを感じさせる構造である。(BCCWJ)

Miru hito-ni atatakami-wo kanji-saseru kōzō dearu.

posmatrač [indir.obj.] osećaj topline [dir.obj.] osećati [kauzativ] struktura [imenski deo predikata]

To je struktura koja u posmatraču izaziva osećaj topline.

4 甘味は，心を和ませ，安らぎを感じさせる心理的な機能もある。（BCCWJ）

Kanmi-wa, kokoro-wo nagomase, yasuragi-wo kanji-saseru shinritekina kinōmo aru.

slatko [subj.] mir [dir.obj.] osećati [kauzativ]

Slatko ima i psihološku funkciju da dovodi psihu u ravnotežu i da umiruje.

Izazivač može biti i personalni argument. Bez obzira na njegovu intencionalnost ili voljnost, on izaziva promenu u doživljavaču nekim svojim činom, kao u primeru 3 hanasouto omotte kita koto-wo, hanaseba ("ako će da mu kaže ono što je nameravala"). Kada je u ulozi izazivača neživi uzročnik, kao u primerima 2-4, promenu 
u doživljavaču izaziva neka njegova posebna osobina, svojstvo ili važnost koju mu izazivač pripisuje. U poslednjoj rečenici doživljavač nije iskazan, čime ona kazuje o uopštenoj osobini uzročnika da izazove određena stanja.

Sledeće rečenice u ulozi objekatske dopune glagola kanjiru imaju apstraktni pojam koji se odnosi na entitet van čoveka, funiki (atmosfera) i rekishi (istorija). Tada se glagol kanjiru koristi i u značenju "doživeti".

5 大型一灯のヘッドライトがどことなく旧型機の雾囲気を感じさせます。（BCCWJ）

Oogata ichi-tō no heddoraito-ga dokotonaku kyūgata-ki no funiki-wo kanjisasemasu.

lampa [subj.]

atmosfera [dir.obj.] osećati

[kauzativ]

Velika lampa sa jednom sijalicom omogućiće vam da osetite atmosferu starih modela.

6 裉せた朱色が歴史を感じさせますね。(BCCWJ)

Aseta shuiro-ga rekishi-wo kanji-sasemasu ne.

skarletna boja [subj.] istorija [dir.obj.] osećati [kauzativ]

Izbledela skarletna boja omogućiće vam da doživite istoriju.

Ako pogledate tu izbledelu skarletnu boju_doživećete istoriju.

Kada je na mestu objekta spoljašnji, apstraktni entitet, za razliku od rečenica gde glagol kanjiru na mestu objekatske dopune ima imenicu osećaja ili osećanja imanentnih čoveku, između kauzativnog i nekauzativnog oblika glagola ne može se uspostaviti odnos prelazno-neprelazno, odnosno kauzativni oblik nema značenje „izazvati osećanje”. To je jasno ako uporedimo primere atatakami-wo kanji-saseru (izazvati osećaj topline) i rekishi-wo kanji-saseru (*izazvati osećaj istorije).

U primerima 5 i 6 doživljavač nije iskazan jer on nije bitan ili je opšti, u značenju "ljudi; svi". Iako je takva rečenica uopštena, upotreba kauzativne strukture naglašava sposonost ili svojstvo entiteta u ulozi izazivača kroz isticanje dejstva koje on ima tek u interakciji sa živim doživljavačem. Interakcija sa doživljavačem, usmerenost pažnje doživljavača na stimulus, kao jedan segment uzročnog lanca (up. Croft, 1993: 59) uslov je da se data sposobnost izazivača ispolji. Uslovljenost pojave dejstva na doživljavača može biti implicitna, iskazana drugim gramatičkim sredstvima u 
japanskom jeziku. $U$ toj ulozi nije retka upotreba odnosne rečenice, ${ }^{10}$ kao u ranije navedenom primeru: Miru hito-ni atatakami-wo kanji-saseru kōzō dearu (To je struktura koja u čoveku koji posmatra izaziva osećaj topline).

U obe rečenice predmeti u ulozi uzročnika, iako zauzimaju poziciju subjekta, istovremeno deluju i kao svojevrstan sprovodnik ili sredstvo pomoću kojeg se ostvaruje dejstvo na doživljavača (Velika lampa sa jednom sijalicom omogućiće vam da posredstvom nje osetite atmosferu starih modela / Izbledela skarletna boja omogućiće vam da posredstvom nje doživite istoriju).

U sledećoj rečenici u ulozi direktnog objekta kauzativnog glagola je imenica kanjō (osećanje, osećaj), uz koju obavezno stoji modifikator.

7 その美しさは見るものにある種の不安定な感情を起こさせるような気がした。 (Murakami, 1988a: 185)

Sono utsukushisa-wa miru mono-ni aru shuno funantēenna …….......... kanjōọ-wo okosaseru yōna ki-ga shita.

lepota [subj.] onaj koji posmatra [indir.obj.] nespokojan osećaj [dir.obj.] izazvati [kauzativ]

Činilo mi se kao da ta lepota budi u posmatraču neki ossećaj nespookoja. (Murakami, 2013: 115)

Kauzirana radnja je izražena glagolom okosu (izazvati, probuditi), a u ulozi modifikatora je pridev fuantēna (nespokojan). I ovde je uz imenicu doživljavača upotrebljena odnosna rečenica (miru mono, onaj koji posmatra) da ukaže na izloženost dejstvu uzročnika kao neophodan uslov za pojavu datog osećanja u doživljavaču.

Glagoli kognitivnih i intelektualnih radnji u japanskom, kao što su sōzō suru (zamisliti) ili omou (misliti), jesu prelazni monotranzitivni glagoli, a u obliku kauzativa postaju ditranzitivni i ukazuju na postojanje spoljašnjeg izazivača:

8 君は俺に何かを連想させる。(Murakami，1988a：343)

Kimi-wa ore-ni nanika-wo rensō saseru.

ti [subj.] ja [indir.obj.] nešto [dir.obj.] povezati [kauzativ]

Podsećaš me na nešto. (Murakami, 2013: 210)

10 Odnosna rečenica u japanskom ima strukturu "glagol u odnosnom obliku + imenica": miru hito (čovek koji posmatra). Pošto glagol u infinitivu u japanskom nema obeležja glagolskog vida, on može da znači i trajnu radnju i početni vid, te bi odnosna rečenica miru hito mogla da ima i značenje: čovek koji se nađe u situaciji da posmatra. 
9 その髪の白さはぼくに、避けがたく、人骨の色を想像させた。(Murakami， 2001： 303)

Sono kami-no shirosa-wa boku-ni, sakegataku, jinkotsuno iro-wo sōzō saseta.

belina kose [subj.]

ja [indir.obj.]

boja

[dir.obj.]

zamisliti [kauzativ]

Ta čista belina njene kose neizbežno mi je prizivala sliku boje ljudskih kostiju. (Murakami, 2004: 207)

10 奥さんの眼は充分私にそう思わせるだけの意味をもっていたのです。(Soseki，1965: 469)

Okusan-no me-wa jūbun watashi-ni sō omowaseru dakeno imi-wo motte ita nodesu.

žena [gen.] pogled [subj.]ja [indir.obj.] misliti [kauzativ]

Njen pogled je bio dovoljno značajan da me u to uveri. (Soseki, 2003: 172)

U primerima 8-10 u osnovi kauzativa su glagoli rensō suru (podsetiti se), sōzō suru (zamisliti) i (sō) omou (misliti (tako)). Ovaj tip rečenice je najmanje restriktivan. U ulozi izazivača-uzročnika može biti i živo i neživo, i za razliku od svih prethodnih tipova rečenice, ne mora imati značenje događaja. On ne mora imati nikakve specifične osobine koje neminovno izazivaju nevoljnu reakciju u doživljavaču. Objašnjenje za to je što doživljavač u slučaju kognitivnih i intelektualnih radnji ima određenu volju i kontrolu nad radnjom (up. Croft, 1993: 62), za razliku od glagola percepcije i emotivnih stanja, koji su reaktivne prirode (up. Popović 2007).

\section{Zaključak}

Kauzativ glagola emocija, percepcije i kognicije u japanskom jeziku spada u kauzativ nevoljnih glagola i izražava uzročno-posledični odnos između onoga koji oseća i onoga koji ili što dato osećanje izaziva, za razliku od prototipične rečenice kauzativa voljnih glagola, koja izražava ciljnousmereno delovanje manipulativnog tipa.

Uvođenjem novog argumenta u ulozi izazivača na poziciju subjekta, glagoli emocija, percepcije i kognicije povećavaju valencu za jedan. Doživljavač se pomera sa pozicije subjekta na poziciju direktnog odnosno indirektnog objekta. Za razliku od prototipične rečenice kauzativa voluntativnog tipa, ovde poziciju subjekta može 
zauzeti i izazivač kojeg odlikuje odsustvo obeležja animatno i voljno. To su izazivači situaitivnog i eventivnog tipa. I kada je izazivač animatni i personalni argument, on nije uzročnik sam po sebi već primarni uzrok postaju njegova osobina, aktivnost, ponašanje. Tako i personalni argument dobija značenje događaja ili propozicionog argumenta.

Kao i u gorepomenutim jezicima, i u japanskom propozicioni argument može da bude ekspliciran na površinskoj ravni rečenice, u vidu zavisne klauze kojom se iskazuje dejstvo izazivača. Najčešće se to čini klauzom u značenju sredstva, načina ili uzroka, ali može da se iskaže i uslovnom klauzom, priloškom odredbom kojom se ukazuje na okolnosti pod kojim se javlja promena stanja, kontekstom u vidu zasebne rečenice ili nezavisne klauze u okviru složene rečenice kada se anaforom upućuje na kauzirajući događaj. Kada je propozicioni argument prikriven, na kauzirajuće dejstvo se upućuje atributivom uz imenicu izazivača ili nominalizovanom dopunom u značenju sredstva ili sprovodnika. Nominalizovana dopuna se može strukturno i semantički objediniti sa subjektom-izazivačem u jedan konstituent, što je takođe uočeno u drugim jezicima. To se u japanskim rečenicama odnosi na slučajeve kada je odnos između izazivača i sprovodnika odnos deo-celina u širem smislu, kao kada je u ulozi „dela" njegov pogled, glas, pitanje i sl.

Kada doživljavač nije iskazan jer nije bitan ili je opšti, kauzativna struktura naglašava sposobnost ili svojstvo entiteta u ulozi izazivača. Neophodan uslov da se data sposobnost ispolji, međutim, jeste interakcija sa doživljavačem kao jedan segment uzročnog lanca, o čemu govori Kroft. Uslovljenost može biti implicitna, iskazana drugim gramatičkim sredstvima, a u zabeleženim primerima na japanskom uočeno je da tu ulogu ima odnosna rečenica.

Rečenica kauzativa kognitivnih glagola pokazuje specifičnost u pogledu odsustva uslovljenosti koje se tiču izazivača, a to se objašnjava time što doživljavač odnosno nosilac kognitivnih i intelektualnih radnji ima određenu volju i kontrolu nad radnjom, za razliku od glagola emocija i percepcije. 


\section{Literatura}

Alanović, M. (2009). Leksičko-sintaksička sredstva pasivizacije. Naučni sastanak slavista u Vukove dane, 38/1, 123-133.

Alanović, M. (2010). Tipološke odlike i principi klasifikacije leksičko-gramatičkih kauzativa. Naučni sastanak slavista u Vukove dane, 39/1, 361-375.

Alanović, M. (2011). Kauzativnost - manipulativnost: od koncepta ka formi. Novi Sad: Filozofski fakultet u Novom Sadu.

Alanović, M. (2012). Kauzativno-manipulativni glagoli: derivaciono motivisane semantičke i argumentne varijacije. Tvorba reči i njeni resursi u slovenskim jezicima: zbornik radova sa četrnaeste međunarodne naučne konferencije Komisije za tvorbu reči pri Međunarodnom komitetu slavista / glavni urednik Rajna Dragićević, 453-467.

Batistić, T. (1978). O nekim aspektima analize kauzativnih glagola. Južnoslovenski filolog XXXIV, 59-86.

Bilandžija, S. (2014). Semantika kauzativnih konstrukcija u norveškom i srpskom jeziku (doktorska disertacija). Beograd: Filološki fakultet. Preuzeto sa https://nardus.mpn.gov.rs/handle/123456789/5037

Croft, W. (1993). Case marking and the semantics of mental verbs. In: Pustejovsky (ed.) Semantics and the lexicon, 55-72.

Cruse, D.A. (1972). A Note on English Causatives. Linguistic Inquiry Vol. 3, No. 4 (Autumn), 520-528. Preuzeto sa https://www.jstor.org/stable/4177739

Glumac, D. (2015). Kauzativ i glagolski rod u japanskom jeziku u poređenju sa srpskim jezikom. Neobjavljena doktorska disertacija. Beograd: Filološki fakultet. https://nardus.mpn.gov.rs/handle/123456789/4286

Glumac, D. (2016). Realizacije japanske kauzativne konstrukcije u srpskom jeziku. U A. Mitrović \& Lj. Marković (ur.), Orijentalistika juče - danas - sutra: međunarodna naučna konferencija. Zbornik rezimea (str. 142-143). Beograd: Filološki fakultet.

Glumac, D. (2016). Tipovi japanske kauzativne rečenice i njihovi prevodni ekvivalenti u srpskom jeziku. U A. Mitrović (prir.), Orijentalističko znamenje - sećanje na Mariju Đukanović (str. 287-297). Beograd: Filološki fakultet.

Glumac, D. (2017). Značenje kauzativa u japanskom jeziku i neki problemi u prevođenju na srpski. Anali Filološkog fakulteta, Knjiga XXIX, Sveska II, 83-99. 
Glumac, D. (2017). Prevođenje japanskog kauzativa posesije sa živim subjektom na srpski jezik. Primenjena lingvistika 18, 7-19.

Hayatsu, E. (1991). Shoyūsha shugo no shieki ni tsuite. Nihongo gakka nenpō 13. Tokio: Tōkyōgaikokugo daigaku, 1-26.

Hayatsu, E. (2004). Shieki hyōgen. Asakuranihongo kōza 6: Bumpō II. Tokio: Asakurashoten, 128-150.

Iori, I. et al. (2002). Chū, jōkyū wo oshieru hito no tame no nihongobumpō handobukku. Tokio: 3A.

Ivić, M. (1983). Lingvističke konsekvence različitog pristupa odnosu 'deo-celina'. Lingvistički ogledi. Beograd: Prosveta, 215-225.

Jamasaki, K. (2014). Gramatika savremenog japanskog jezika. Beograd: Zavod za udžbenike i nastavna sredstva.

Kovačević, M. (1988). Uzročno semantičko polje. Sarajevo: Svjetlost, 1988.

Kuroda, S.Y. (1965). Generative Grammatical Studies in the Japanese Languages, Ph.D. Dissertation, MIT. Preuzeto sa https://dspace.mit.edu/handle/1721.1/13006

Lyons, J. (1977). Semantics, Vol.2, Cambridge University Press.

Levin, B. (1993). English verb classes and alternations. A preliminary investigation. University of Chicago Press.

Milenković, A. (2015). Semantičke uloge doživljavača i izazivača emocije u značenjskoj strukturi emocionalnih glagola u srpskom jeziku. Naš jezik XLVI/3-4, 23-38.

Morita, Y. (1971). Ukemi-shieki no iikata. Kouza Nihongo kyouiku 9. Tokio: Waseda Daigaku Gogaku Kenkyuujou, 18-42.

Moskovljević-Popović, J. (2007). Klase glagola za izražavanje psiholoških stanja, osećanja i raspoloženja u savremenom srpskom jeziku. Naučni sastanak u Vukove dane, sv. 37/1, 87-98.

Piper, P. i dr. (2005). Sintaksa savremenog srpskog jezika. Prosta rečenica. Red. Milka Ivić. Beograd: Institut za srpski jezik SANU, Beogradska knjiga; Novi Sad: Matica srpska.

Popović, Lj. (2007). Argumentska struktura glagola emotivnog stanja u slovenskim jezicima. Zbornik Matice srpske za slavistiku 71/72, 481-497.

Ristivojević-Rajković, N. (2017). Leksičko-semantička analiza glagola sa osnovnim značenjem 'udariti' u norveškom i srpskom jeziku: kontrastivna analiza (doktorska disertacija). Beograd: Filološki fakultet. Preuzeto sa https://nardus.mpn.gov.rs/handle/123456789/9076 
Satō, S. (1986). Shiekikōzō no bun. Kotobano kagaku 1. Tokio: Gengogaku kenkyūkai, 89-179.

Satō, S. (1990). Shiekikōzō no bun (2): gen'in kankei wo hyougen suru baai. Kotobano kagaku 4 Gengogaku kenkyuukai. Tokio, 103-157.

Shibatani, M. (1973). Semantics of Japanese Causitivization. Foundations of Languages 9, 327-373.

Suzuki, Sh. (1972). Nihongobunpō - kētairon. Tokio: Mugishobō.

Stojanović, S. (1996). Binarne relacije posesije u engleskom i srpskohrvatskom jeziku. Beograd: Filološki fakultet.

Štrbac, G. (2006). O valentnosti glagola emocionalnog sadržaja u srpskom jeziku. Zbornik Matice srpske za filologiju i lingvistiku, vol. 49, br. 2, 73-102.

Takahashi, T. (2005). Nihongo no bunpō. Tokio: Hitsuji.

Teramura, H. (1982). Nihongo no shintakusu to imi I. Tokio: Kuroshio shuppan.

Van Valin, R. D. Jr., \& R. J. LaPolla. (1997). Syntax: Structure, meaning and function. Cambridge University Press.

\section{Izvori}

Akutagava, R. (2002). Nos. Beograd: Rad.

BCCWJ. Preuzeto sa https://shonagon.ninjal.ac.jp/

Hana. Preuzeto sa http://www.aozora.gr.jp/cards/000879/files/42 15228.html

Gan. http://www.aozora.gr.jp/cards/000129/files/45224 19919.html

Murakami, H. (1988a). Dansu Dansu Dansu I. Tokio: Kodansha.

Murakami, H. (1988b). Dansu Dansu Dansu II. Tokio: Kodansha.

Murakami, H. (2001). Supuutonikuno koibito. Tokio: Kodansha.

Murakami, H. (2004). Sputnik ljubav. Beograd: Geopoetika.

Murakami, H. (2013). Igraj igraj igraj. Beograd: Geopoetika.

NIDS.

Preuzeto

sa

http://www.nids.mod.go.jp/event/proceedings/forum/pdf/2010/11.pdf

Ogai, M. (2014). Divlja guska. Beograd: Tanesi.

Soseki, N. (2003). Duša. Sombor: Publikum.

Soseki, N. (1965). Kokoro. Nihonno bungaku 13. Tokio: Chukoronsha. 


\section{Summary}

\section{JAPANESE CAUSATIVE CONSTRUCTIONS WITH THE VERBS OF EMOTION, PERCEPTION AND COGNITION}

The paper deals with Japanese causative sentences that express emotions, perception and cognition. They have a peripheral position when talking about causative due to the fact that a two-agent causative sentence is considered prototypical. The aim of this paper is to point out the specifics of causative verbs of emotion and mental actions in comparison with a prototypical, two-agent causative sentence. The second goal is to highlight the characteristics of causative verbs of emotion, observed in some languages such as English and Serbian, which also appear in Japanese. Using the method of semantic analysis, we will shed light on the argument structure of causative form of the verbs from the perspective of semantic roles that are assigned to the syntactic positions of the subject and the object of the sentence, with a special emphasis on the role of the subject. We will also consider the notions of volition and intentionality.

The causative of the verbs of emotion, perception and cognitive verbs in Japanese belongs to the causative of involuntary verbs and expresses the cause-and-effect relationship between the one who experiences and the one who causes an emotion, unlike the prototypical sentence of causative of voluntary verbs, which expresses intentional manipulative action.

Unlike the prototypical sentence in causative of the voluntary type, the subject position can be taken by a stimulus characterized by the absence of features of animacy and volition as well. These are stimuli of the situational and eventual type. Even if the stimulus is an animate and personal argument, he or she is not the causer per se. It is his or her feature, activity or behavior that becomes the primary cause of a change in the experiencer. Thus, the personal argument is given the meaning of an event or propositional argument. The propositional argument can be explicated on the surface of a sentence, in the form of a dependent clause expressing the action of the stimulus. This is one of the features that have been observed both in Japanese and in aforementioned languages.

The features of causative sentences were collected from examples from the works of contemporary Japanese authors and their translations into Serbian. We partially used data from the Corpus of Contemporary Japanese Written Language (BCCWJ) of the National Institute of Japanese Language and Linguistics (NINJAL).

Key words: causative, Japanese, verbs of emotional state, verbs of psychological state, stimulus, experiencer. 